Музеј жртава геноцида, Београд;

Архив Југославије, Београд

DOI 10.5937/kultura1964247D

УДК 351.758.5(497.1)"1920/1930"(093.2)

7.025:271.222(497.113)-523.4"1920/1930"(093.2)

оригиналан научни рад

\title{
OKOMИCUJAMA 3A
}

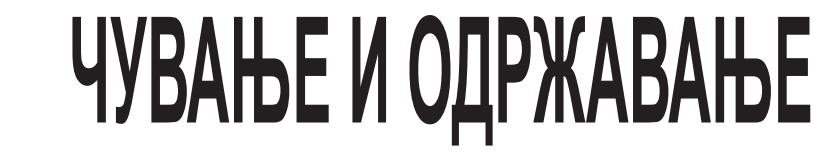

BEPCKИX OБJEKATA CPICKE

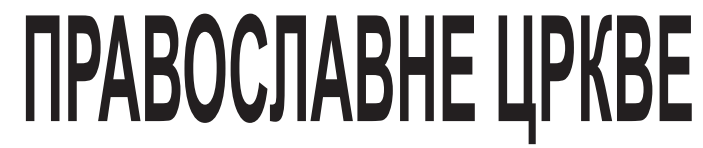

И3MEDY ABA CBETCKA PATA

Сажетак: Архијереји Српске православне иркве су, после успостављања Патријаршије (1920), планирали обнављање и рестаураиију храмова широм прве јужнословенске државе, проглашене 1. децембра 1918. године. За реализачију тих планова формиране су и надлежне комисије. Овај текст представља хронолошку реконструкиију настајања тих комисија, засновану само на доступној аутентичној, веродостојној и оригиналној архивској грађи, која се чува у Архиву Југославије. Како у истраживању није било могуће доћи до комплетне грађе, јасно је да у юему има и одређених празнина, али оне, ипак, драстично не нарушавају разумевање главнине текста у ређању догађаја.

Кључне речи: Српска православна ирква, Министарство вера, архитектонски споменици, министар, комисија, чување, рестаурација

Тешко је утврдити ко је и када, после Првог светског рата, поменуо питање чувања и одржавања сакралних објеката храмова и манастира - Српске православне цркве. 
Министар вера, др Војислав Јанић, је 24. децембра 1923. припремио предлог за Министарски савет Краљевине Срба, Хрвата и Словенаца о саставу Комисије за чување и одржавање архитектонских споменика и том приликом предложио: председник проф. др Милоје Васић, и чланови Пера Поповић, начелник Министарства грађевина, проф. др Владимир Петковић, проф. др Владимир Ћоровић и др Радивоје Јосић, доцент Теолошког факултета.

„Комисија има одмах да отпочне рад у повереном ми Министарству са особљем које јој будем ставио на расположење. Она ће претходно, за свој унутрашњи рад израдити правилник, с обзиром на захтеве модерне науке и искуства о чувању и одржавању оваквих споменика у осталим културним државама Европе.

Тај Правилник ће по моме одобрењу објавити поверено ми Министарство.

За претходне и редовне радове ове врсте предвиђена је у парт. 1356 државног буџета за 1922/23 год. сума од 700.000 динара. Од ове суме у колико није утрошена, ставио ми је Господин Министар грађевина одлуком својом Бр. 28948/23 на расположење: 218.508 динара. Ова је сума према акту Министарства грађевина Р. бр. 7524/23. год. и извештај Народне банке положена у депозит Народне банке, и трошиће се по одредбама закона о државном рачуноводству.

У колико даље буде било потреба материјалних, надокнађиваће се из редовног буџета Министарства Вера, зашто је унесена и потребна сума.

На име дневница за рад комисије у Београду, кад комисија ради, одредити претседнику 120 дин. дневно, техничком шефу 100 дин. дневно, а члановима по 80 дин. дневно.

За радове на терену, чланови имају право на принадлежности, предвиђене зак. о накнади трошкова држ. службеника кад путују службено.

Ова комисија има давати своје мишљење и по свима предлозима духовних власти, кад се обраћају Министарству вера у циљу оправака и рестаурације црквених и манастирских грађевина (цркава)."1

Министарски савет је, на својој седници одржаној 24. децембра 1923. године, прихватио Правилник Комисије за чување и одржавање националних споменика (манастира,

1 Решење Министарског Савета Краљевине Срба, Хрвата и Словенаца, В. Бр. 15703 од 24. децембра 1923. године - Архив Југославије (АЈ), Министарство правде Краљевине Југославије (63), стр. 7. 
цркава, градова итд.) у коме се, између осталог, каже да је Комисија образована при Министарству вера с циљем чувања и одржавања националних споменика (Чл. 1.) и то првенствено на територији Србије, Црне Горе и Војводине, а по потреби и осталих споменика у Краљевини, о чему одлуку доноси министар вера, по претходно прибављеном мишљењу Комисије (Чл. 2.). ${ }^{2}$

Министарски савет је на својој седници од 31. децембра прихватио предлог министра вера о Комисији. ${ }^{3}$

Синод је 16/29. марта 1927. доставио Министарству вера своје примедбе на предложени Закон о заштити историјских верских споменика „који је Министарство Вера у своје време спремало за финансијски Закон."

Министарство вера је 9. априла одговорило Синоду истичући да оно нема никакав предлог закона о заштити верских споменика додавши: „Постоји одлука Министарског Савета ВБр. 15703 од 24-ХІІ-923 г., којом је образована Комисија за чување и проучавање архитектонских споменика и она ради и данас, под председништвом Др Милоја Васића проф. Универзитета."

Свети архијерејски Синод Српске православне цркве је сматрао да и Црква треба да буде укључена у обнову манастира и зидање храмова. Тешко је утврдити када је то званично казано. Тај захтев одразио се на однос Синода и представника Министарства вера.

Министарство вера је формирало своју комисију и о томе 14. априла 1927. обавестило Синод. Синод је 2/15. јуна тражио да у комисију уђе и представник Српске православне цркве. ${ }^{6}$

Министарство вера је прихватило Синодов захтев и уврстило свештеника др Радивоја Јосића, професора Богословског

2 Исто. Постоји и руком писани Правилник који су 24. фебруара 1920. (вероватно се ради о грешци, па треба да стоји 1923) потписали Милоје М. Васић, председник и Владислав Р. Петковић, Владимир Ћоровић и Радивоје Јосић, чланови.

3 Решење Министарског Савета Краљевине Срба, Хрвата и Словенаца, од 31. децембра 1923. године - АЈ, 63, 7.

4 Писмо Синода Српске православне цркве, Син. Бр. 558/зап. 470 од 16/29. марта 1927, Министарству вера - АЈ, 63, 7.

5 Писмо Министарства вера, ВБр. 4395 од 9. априла 1927, Синоду - АЈ, $63,7$.

6 Писмо Синода, Син. бр. 957/зап. 663 од 2/15. јуна 1927, министру вера AJ, 63, 7 . 
факултета, за члана Архитектонске комисије. о томе је 28. јуна обавестило Синод. ${ }^{7}$

Синод је, 21. јуна / 4. јула 1927. обавестио министра вера да је прихватио тај избор и нагласио да је он његов делегат „и да као такав обавезан подносити свој извештај Светом Синоду о раду те комисије". ${ }^{8}$

Министарство вера је о именовању свештеника Јосића обавестило председника Комисије и Деканат Богословског факултета. $^{9}$

Синод је 1. септембра 1928. обавестио Министарство вера да професора Радивоја Јосића не сматра својим делегатом у Комисији. „Разлог је, што као делегат Светог Архијерејског Синода није до сада поднео ни један извештај Светом Архијерејском Синоду о раду Комисије за чување и одржавање архитектонских споменика и ако је на то био обавезан, по гласу Синодове одлуке Син. бр. 1442/зап. 894/1927. год., која му је у своје време саопштена." 10

У наставку писма Синод је тражио:

„Част Нам је умолити Вас Господине Министре, да изволите известити Свети Архијерејски Синод: како је у опште дошло до образовања Комисије за чување и одржавање Архитектонских Споменика, без знања и суделовања Светог Архијерејског Синода, као највише извршне власти управне и надзорне (чл. 5 Уредбе) у Српској Православној Цркви, иако су ти црквено-манастирски споменици у првом реду својина Српске Православне Цркве.

Част Нам је умолити Вас господине Министре и за извештај: какав је делокруг поменуте Комисије и има ли та Комисија свој Правилник. По акту Министарства Вера ВБр. 4395/14. IV. 1927, тај Правилник требао је до сада бити прописан, а пре него што буде потписан, требао је бити послан Светом Архијерејском Синоду на увиђаје.

Част је Светом Архијерејском Синоду умолити и за извештај: у каквом односу стоји поменута Комисија према Вама Господине Министре, да ли је она Ваш експерт или орган; у

7 Писмо Министарства вера, В. Бр. 7881 од 28. јуна 1927, Синоду - АЈ, 63, 7.

8 Писмо Синода, Син. бр. 1442/зап.894 од 21. јуна/4. јула 1927, министру вера - АJ, 63, 7.

9 Писмо Министарства вера, В. Бр. 8646 од 13. јула 1927, председнику Архитектонске комисије и Синоду - АJ, 63, 7.

10 Писмо Синода, Син. бр. 1505/зап. 721 од 1/14. септембра 1928, министру вера - AJ, 63, 7. 
каквом односу стоји та Комисија према Српској Православној Цркви, јер су поменути споменици у првом реду својина Српске Православне Цркве.

Све ово потребно је да се правилно регулише и да се тачно зна, да би се избегли неспоразуми о субјективном праву (овлашћењу) и нежељени сукоби.

Част Нам је умолити Вас Господине Министре, да овај предмет изволите сматрати хитним." 11

Судећи по новом писму Синода министру вера, од 7/20. октобра 1928, може се рећи да министар није одговорио на писмо. На самом почетку Синод је поменуо своје писмо од 1/14. септембра. Потом је нагласио:

„Господине Министре, установа Архитектонска Комисија, добро и правилно организована, без сваке сумње, била би врло умесна и корисна ствар. Како државни и национални, тако исто и црквени интереси траже, да се обрати пуна пажња на старе црквене архитектонске споменике; да се путем умесне рестаурације одржавају, као дика и понос наше старе религиозности; културе и уметности, а не мање, да се у вези са тим и наслањајући се на то, и у напредак ради стварања српског црквеног архитектонског стила. Ми имадемо, хвала Богу, врло много дивних споменика - старина, који представљају велико дело уметности не само за нашу Цркву, него и за Народ и Државу. Сама Црква нема потребних средстава за чување и одржавање тих дивних споменика, па је еминентна дужност Државе, да ју у том правцу помогне. Јасно је, према реченом, да је и Цркви и Држави потребна установа Архитектонске Комисије, али правилно и добро организоване. Да би рад те Комисије могао бити успешан и користан, безусловно је потребна тесна споразумна сарадња Цркве и Државе. Споразумно би се имао утврдити састав и круг рада те Комисије; однос њен према Цркви и држави; осигурати у довољној количини потребна материјална средства за њезин успешан рад, предвидети и регулисати и друге нужне појединости. У том смеру ваљало би споразумно израдити добар Правилник, у коме би тачно и јасно били обележени права и дужности те Комисије. Тако би се избегли нежељени сукоби и не би се догађали немили и штетни случајеви слични онима: у манастиру Жича, са катедралом у Чачку, у некојим црквама и манастирима Скопљанске Епархије, Манастир Сопоћани, манастир Грачаница и други.

Комисији би се у првом реду имала ставити у задатак да тачно одреди, који од старих споменика имају архитектонску

11 Исто. 
вредност и који од њих уопште заслужују, да се ставе под нарочиту бригу и старање Комисије, а који не. Они такови споменици имали би се инвентарисати и описати, и све то држати тачно и савесно у евиденцији. Споменици би се, даље, могли разврстати по групама, од веће или мање вредности и важности, које треба одмах, а које касније оправљати, према њиховом оронулом стању. Даље, потребно је, да се повуче тачна граница између грађевина, чије би одржавање спадало у заједничку надлежност Цркве и Архитектонске Комисије, и између споменика, који се могу оправљати и у опште одржавати без сарадње са том Комисијом, и т. д.

Част Нам је умолити Вас, Господине Министре, да свему овде изложеноме изволите поклонити Вашу озбиљну пажњу и добру вољу у интересу драгоцених споменика наших, дике и поноса Цркве и Државе, а и ради избегавања нежељених сукоба о надлежности, у којима се троши само енергија, тако драгоцена и неопходно потребна, да се утроши у многе послове, корисне и по Цркву и по Државу, који чекају на своје извођење и довршење.."12

Синод је и 25. октобра још једном писао министру вера. Повод су била писма Министарства вера упућена Духовном суду епархије Скопљанске и митрополиту скопљанском Варнави о стању неколико манастира. После разматрања ових писама, Сабор је донео следеће закључке:

„1. Св. Арх. Сабор енергично протествује преко Светог Арх. Синода код г. Министра Вера, што је без претходног споразума са Св. Арх. Синодом у погледу надлежности и обима рада ове Комисије овој дато широко право мешања у послове Цркве тамо, где је позитивно право, канони и опште уређење Цркве то оставило и загарантовало компетенцији црквених власти Св. Арх. Сабор тражи, да се рад ове Комисије доведе у склад са законским прописима и правилима Цркве; да се њена самовоља сузбије, а црквеним властима остави слобода рада у границама постојећег закона.

2. Да се започети објекти рестаурирања старих цркава и манастира, које је државна власт преко ове Комисије узела на себе, у најкраћем времену доврше и тако спасу од квара и коначног пропадања.

Да се сви ови важни објекти наших црквено-народних старина којима грози скоро уништење, ако се оставе досадашњем нехату и елементарним непогодама, одмах сходним начином зештите од квара и пропасти, али да се то ради и

12 Писмо Синода, Син. бр. 1909/зап. 1111 од 7/20. октобра 1928, министру вера - AJ, 63, 7 . 
уради у договору у складу са надлежним представницима Цркве.

3. Ради очувања свих важних црквено-манастирских старина свих врста и ради загарантовања свих црквених права на исте Св. Арх. Сабор ставља Св. Арх. Синоду у дужност, да хитно настави започети рад на доношењу закона о заштити црквено манастирских старина.

\section{4. Да Архитектонска комисија буде при Св. Арх. Синоду.”13}

Министар вера је одговорио тек 28. јануара 1929. На самом почетку је истакао да су споменици тековина српске културе али и целог човечанства па се стога морају брижљиво чувати. Потом је навео да је било случајева таквог руковања које је имало лоше последице што га је навело да поново узме у разматрање и решавање спорних ствари.

„Ово чиним из разлога, а главни су, што не желим да понесем одговорност пред историјом, пред јавношћу и пред културним светом, ако би се сва наша драгоценост, кроз векове очувана од непријатеља, и коју зуб времена није могао потпуно да уништи, буде упропашћена немарним и нестручним руковањем. Сем тога, факат, да највиши наши кругови и највише личности инсистирају на томе, да буде очувано све оно што је до нас дошло, руководи ме, такође, да поклоним овоме предмету особиту пажњу.

Поред тога, факат, да представници других хришћанских Цркава и представници других земаља, сматрајући ове споменике као културну тековину целога света, коју треба очувати по сваку цену, нуде материјалну помоћ за одржавање и рестаурирање њихово под извесним условима које ми не можемо усвојити у интересу угледа Цркве и Државе, ставља ми категорички у дужност, да ово питање расправим у што краћем року.

Са тога разлога намеран сам предложити на Надлежном Месту законски пројекат, којим ће ово питање бити регулисано.

Пре него што учиним предлог на Највишем Месту, мени је част у прилогу под ./. доставити у овереном препису пројект овог закона с молбом, да ми Свети Архијерејски Синод изволи доставити своје мишљење и евентуалне примедбе на предложени пројект." 14

13 Писмо Синода, Син. бр. 2106/зап. 1151 од 25. октобра/7. новембра 1928, министру вера - AJ, 63, 7 .

14 Писмо Министарства вера, В. Бр. 1078 од 23. јануара 1929, Синоду - АЈ, 63,7 . 
Министар је одговорио и 29. јануара 1929. нагласивши да је вољан да усвоји Синодове предлоге и додао да је његов претходник спремио помињани Правилник. Понудио је Синоду да састави предлог правилника и достави му га на разматрање и, евентуално, усвајање. На крају је молио предлог новог члана комисије уместо професора Јосића. ${ }^{15}$

Предлог закона о заштити споменика који је помињао министар је гласио:

„Ми

Александар I

По милости Божјој и вољи народној

Краљ Срба, Хрвата и Словенаца

прописујемо и проглашујемо

Закон

о заштити историско-архитектонских споменика

Члан 1.

Сви историско-архитектонски споменици из прошлости од културно-историјске важности, били они у целости или у развалинама, са потребном просторном околином и приступом, као и са свима оним историским предметима свију врста, који се при манастирима, црквама или иначе налазе, или се буду нашли, јесу неотуђиво опште-народно добро и ради очувања њихова подлеже заштити и надзору државном преко представника Цркве и политичких власти а под врховним надзором Министра Вера.

Члан 2.

Који су од ових споменика од културно-историске важности утврђиваће Министар Вера у споразуму са Комисијом за историско-архитектонске споменике при Министарству вера и са Консерваторским уредима.

\section{Члан 3.}

За спровођење предњих законских наређења, Министар Вера ће прописати Уредбу, а Комисија за историско-архитектонске споменике при Министарству вера има дужност да се стара о свестраном извођењу циљева напред изложених, ради чега ће се уносити у буџет Министарства вера потребна сума.

15 Писмо министра вера, од 24. јануара 1929, Синоду - АЈ, 63, 7. 
Члан 4.

Овај Закон вреди чим се обнародује у Службеним Новинама."

Тешко је утврдити који су били разлози за оставке већине чланова Архитектонске комисије. Министар правде је 3. јуна 1930. разрешио и преостале чланове Владимира Петковића и Владимира Ћоровића. У акту разрешења писало је и следеће: „Комисија за чување и одржавање архитектонских споменика Српске Православне Цркве конституисаће се и постојати на даље при Патријаршији Српске Православне Цркве и у смислу решења Министарског Савета Бр. 15703 од 24-XII-1923 год. отправљати послове под руководством Његове Светости Патријарха и мојим надзором ради чега умолити Његову Светост, да ми предложи лица на постављење.

Трошкови рада Комисије покриваће се и даље из буџетских кредита повереног ми ресора и средстава која Српска Православна Црква сама пружи за ту сврху.”16

Решење је тек 3. септембра упућено патријарху. ${ }^{17}$

У међувремену, Синод је одговорио министру правде на његово писмо од 13. јуна 1930. обавестивши га да је Синод закључио да „Стручна комисија за чување и рестаурацију цркава и манастира треба да постоји при Патријаршији. Када се начелно буде усвојило гледиште Светог Архијерејског Синода да поменута комисија буде при Патријаршији, тада се има приступити избору личности које треба да уђу у Комисију, као и изради правилника за рад комисије.”18

Патријарх Варнава је 17. августа 1930. тражио од министра правде да Ђурђа Бошковића, кустоса Народног музеја, ставе на располагање како би могао да ради на рестаурацији манастира. Министар правде је уважио молбу и о томе обавестио и министра просвете Божу Максимовића. У том писму је тражио да Бошковића ослободи других обавеза. ${ }^{19}$

Патријаршија је 17. септембра 1930. обавестила министра правде Милана Сршкића о извештају Ђурђа Бошковића, стручњака који је обишао манастир Пећке патријаршије и затражио помоћ ради наставка обиласка манастира Пећке

16 Решење министра правде, Бр. 57178 од 13. јуна 1930. године - АJ, 63, 7. 17 Писмо Министарства правде, Бр. 64534 од 23. августа 1930, Синоду AJ, 63, 7.

18 Писмо Синода, Син. бр. 1772/зап. 847 од 7/20. јуна 1930, министру правде - АЈ, 63, 7.

19 Писмо министра правде, бр. 80060 од 20. августа 1930, министру просвете - АЈ, 63, 7 . 
патријаршије, Старо и Младо Нагоричане, Нерези и Каленић и припреме извештаја о стању и потребним радовима заштите. ${ }^{20}$

По свему судећи, Синод је помогао да неки чланови Комисије дају оставке. Имајући ово у виду, министар правде je 23. августа 1930. донео решење којим је разрешио преостале чланове др Владимира Петковића и др Владимира Ћоровића чланства у Комисији.

У истом решењу је закључио:

„Комисија за чување и одржавање архитектонских споменика Српске Православне Цркве конституисаће се и постојати на даље при Патријаршији Српске Православне Цркве и у смислу решења Министарстког савета Бр. 15703 од 24XII-1923 год. отправљати послове под руководством Његове Светости Патријарха и мојим надзором ради чега умолити Његову Светост, да ми предложи лица за постављење.

Трошкови за рад Комисије покриваће се и на даље из буџетских кредита повереног ми ресора и срестава која Српска Православна Црква сама пружи за ту сврху."21

Решење је достављено и Синоду.

Синод је 3. септембра / 21. августа 1930. одговорио да ће именовати једног архијереја за председника Комисије и да ће у њу бити изабрани архитекта Бранко Таназевић професор Архитектонског факултета, Драгутин Маслаћ саветник Министарства грађевина, Александар Дероко доцент и Ђурђе Бошковић, кустос Народног музеја. ${ }^{22}$

Министарство правде је прихватило предлог Синода и о томе донела одговарајуће решење о постављењу. ${ }^{23}$ Потом су 5. септембра обавестили Главну контролу. Главна контрола је примила на знање писмо и одговорила 27. септембра 1930. са подацима о принадлежностима које припадају новоизабраним члановима: Бранку Танасковићу, Драгутину Маслаћу, Момиру Коруновићу, Ђурђу Бошковићу и Живадину Радосављевићу. ${ }^{24}$

20 Писмо Патријаршије, А.Е.П. бр. 2018 од 17. августа 1930, министру правде - АJ, 63, 7.

21 Решење министра правде, Бр. 64534 од 23. августа 1930. године - АJ, 63, 7.

22 Писмо Синода, Син. Бр. 2497/зап. 1036 од 21. августа / 3.септембра 1930, министру правде - АЈ, 63, 7.

23 Решење Министарства правде, Бр. 84585 од 4. септембра 1930. године AJ, 63, 7.

24 Писмо Главне контроле, Бр. 84406 од 27. септембра 1930, Министарству правде - АЈ, 63, 7. 
Министарство правде је инсистирало да Синод одреди председника Комисије. Синод је одговорио 24 / 11. септембра да је одредио митрополита Јосифа за председника Комисије. ${ }^{25}$

Министарство правде је, 23. августа 1930. године, тражило од Министарства просвете сагласност да кустос Бошковић може да буде члан Комисије. Позитиван одговор је упућен 15. септембра: „У вези тражења господина Министра правде бр. 80060/XII од 23 августа ове године, Министарству просвете част је известити да је Министар просвете одлуком Ф. бр. 32494 од 15. овог месеца одобрио да се г. Бошковић Ђурђе, кустос Музеја српске земље у Београду, сада на раду у Историјско-уметничком музеју у Београду, додели на рад Синоду Српске православне цркве за време од три месеца". ${ }^{26}$

По пријему овог писма, министар просвете је обавестио Синод и патријарха Варнаву. ${ }^{27}$

Синод је 24 / 11. септембра 1930. тражио од Верског одсека Министарства правде да му уступи све материјале везане за рад некадашње Комисије а нарочито оне које се односе на „грађење и рестаурирање цркава и манастира, као и подизање црквених домова и томе слично". ${ }^{28}$

Синод је 31/18. јануара 1931. обавестио Министарство правде да је предложио за члана Комисије др Владимира Петковића, професора Универзитета и управника Историјскоуметничког музеја у Београду. У наставку је обавестио да је и Министарство просвете именовало исту личност за свога представника. ${ }^{29}$

Министарство правде је 10. фебруара 1931. усвојило предлог Синода и о томе га обавестило као и Министарство просвете. ${ }^{30}$

Божидар Максимовић, министар правде обавестио је 30. јануара 1933. Милана Сршкића, председника Министарског

25 Писмо Синода, Син. Бр. 2745/зап. 1229 од 24/11. септембра 1930, министру правде - АJ, 63, 7 .

26 Писмо Министарства просвете, П. Бр. 32494 од 15. септембра 1930, Министарству правде - АЈ, 63, 7.

27 Писмо Министарства правде, Бр. 89107 од 18. октобра 1930, патријарху Варнави - АЈ, 63, 7.

28 Писмо Синода, Син. бр. 2475/зап. 1229 од 24/11. септембра 1930, Верском одсеку Министарства правде - АЈ, 63, 7.

29 Писмо Синода, Син. Бр. 146/зап. 93 од 31/18. јануара 1931, министру правде - АЈ, 63, 7.

30 Писмо Министарства правде, бр. 15162 од 10. фебруара 1931, Синоду и Министарству просвете - АЈ, 63, 7. 
савета о историјату Комисије, пословима које је обавила, променама у односу према Министарству вера, односно правде и Патријаршији, саставу и тако даље. Потом је писао: „Како је сад Министарство војске и морнарице покренуло питање за одржавање смедеревског града и Министарство просвете упутило предмет за пом. Комисију и како ова комисија при Патријаршији искључиво ради на обнови и одржавању цркава и манастира Српске Православне Цркве са кредитом додељеним Српској Православној Цркви мени је част доставити Вам, Господине Председниче, предмет о рестаурацији смедеревског града, који је такођер један историјски споменик за наш народ, с молбом за одлуку коме ће се телу доделити овај посао у рад и из којих ће се кредита плаћати." 31

Синод је 1. септембра/29. августа 1933. обавестио Министарство правде да секретар Комисије Живадин Радосављевић не станује у месту где се одржавају седнице па ће дужност деловође обављати Драгољуб Милојковић, чиновник Синода. ${ }^{32}$

\section{ИЗВОРИ:}

Архив Југославије, Министарство правде Краљевине Југославије.

31 Писмо Министарства правде, бр. 124871/32 од 30. јануара 1933, председнику Министарског савета - АJ, 63, 7.

32 Писмо Синода, Син. Бр. 9431/зап. 1992 од 1. септем,бра/18. августа 1933, Министарству правде - АЈ, 63, 7. 
Veljko Đurić Mišina and Miloš Crnomarković Museum of the Genocide Victims, Belgrade Archive of Yugoslavia, Belgrade

\title{
ABOUT COMMISSIONS FOR PRESERVATION AND MAINTENANCE OF RELIGIOUS FACILITIES OF THE SERBIAN ORTODOX CHURCH BETWEEN THE TWO WORLD WARS
}

\begin{abstract}
After establishment of the Patriarchate, the archpriests of the Serbian Orthodox Church planned renovation and restauration of the temples throughout the first South Slavic country proclaimed on 1st December 1918. For the realization of these plans, competent commissions were formed. This paper provides a chronological reconstruction of events that occurred during formation of these commissions as well as the problems in the relationships of the Ministry of religion and justice and of the Holy Archpriest Synod of the Serbian Orthodox Church, regarding composition and jurisdiction over these commissions which was first granted to the said Ministry and then transferred to the Patriarchate of the Serbian Orthodox Church.
\end{abstract}

Key words: Serbian Orthodox Church, Ministry of religion, architectural monuments, minister, commission, restauration, renovation

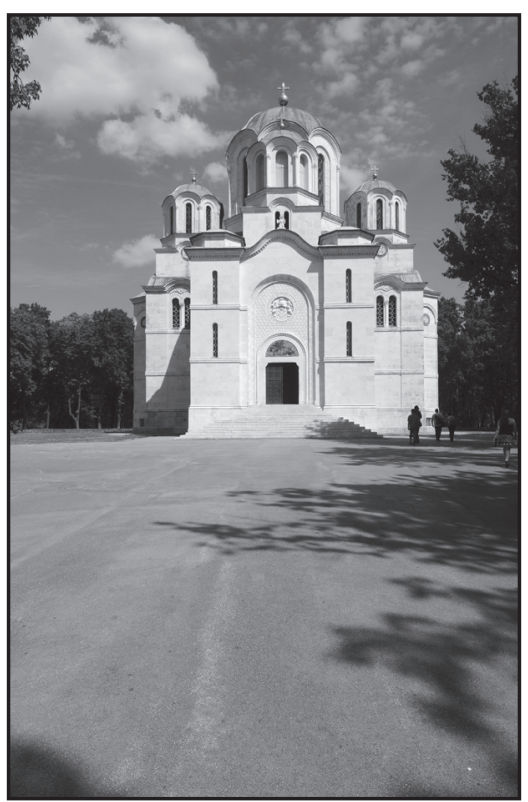

Црква Светог Ђорђа, Опленац, Топола; фото: Рајко Р. Каришић 